\title{
Analyses of Different Adhesives on Pure Mode I and Mode II Delamination Growth of Composite Bonded Joints ${ }^{+}$
}

\author{
Sara Sánchez ${ }^{1, *}$, Patricia Coronado ${ }^{2}$, Antonio Argüelles ${ }^{1}$ and Jaime A. Viña ${ }^{2}$ \\ 1 Department of Construction and Manufacturing Engineering, University of Oviedo, Edificio \\ Departamental Oeste n7, Campus de Viesques, 33203 Gijón, Spain; antonio@uniovi.es \\ 2 Department of Materials Science and Metallurgical Engineering, University of Oviedo, C/Independencia 13 \\ s/n, 33004 Oviedo, Spain; coronadopatricia@uniovi.es (P.C.); jaure@uniovi.es (J.A.V.) \\ * Correspondence: uo186993@uniovi.es; Tel.: +34-717-719-381 \\ + Presented at the 2nd International Research Conference on Sustainable Energy, Engineering, Materials and \\ Environment (IRCSEEME), Mieres, Spain, 25-27 September 2018.
}

Published: 27 November 2018

\begin{abstract}
This work aims to study the behaviour against delamination under static modes I and II of adhesive bonded joints in unidirectional carbon-fibre/epoxy prepreg. The double cantilever beam and end notched flexure tests were used to characterize the influence on the interlaminar fracture toughness under pure mode I and pure mode II, respectively. Three structural adhesives from different manufacturers were tested in comparison with the original material, that is, without adhesive bonded. The fracture surfaces were also examined for each joint system.
\end{abstract}

Keywords: composites; delamination; adhesive; fracture

\section{Introduction}

The application of adhesive bonds in structural components of fibre reinforced polymers has been increased in recent years. This is mainly due to the great advantages over other joining methods, improvements in the strength/weight ratio, load transfer through the adhesive, design flexibility and lower costs. On the contrary, surfaces preparation, adherents and adhesives types, the joint thickness and the temperature, must be studied during the manufacturing process [1]. It is known that the joining method is influenced by the breaking process, the way of breaking and the strength of the joint $[2,3]$.

\section{Materials and Manufacture of Joints}

The adherends of the specimens were prepared considering unidirectional $0^{\circ}$ layups carbonepoxy prepreg (MTC 510) using a vacuum bagging layup procedure similar to that used in industry and a $100{ }^{\circ} \mathrm{C}$ cured during $4 \mathrm{~h}$. Each laminate consisted of 7 plies of MTC 510. Secondary bonded joints were produced by curing a single sheet of adhesive between two pre-cured laminates [4]. A 12 $\mu \mathrm{m}$ thick PTFE sheet was placed between the laminate and the adhesive on one side of the layup to act as a crack initiation.

Three structural adhesives (see Table 1); two epoxy adhesives (Loctite ${ }^{\circledR}$ EA 9470TM and Araldite ${ }^{\circledR}$ 2015) and acrylic adhesive 3MTM DP8010NS) were used to bond the adherends, whose surface were previously roughened with sandpaper and cleaned with acetone in order to increase the adhesion thus avoiding adhesive failure. 
Table 1. Mechanical properties of three different adhesive tested.

\begin{tabular}{|c|c|c|c|}
\hline Properties & Loctite $^{\circledast}$ EA 9470 ${ }^{\mathrm{TM}}$ & Araldite $^{\circledR} 2015$ & 3M $\mathrm{M}^{\mathrm{TM}}$ DP8010NS \\
\hline Structural base & Epoxy & Epoxy & Acrylic \\
\hline Density, $\mathrm{g} / \mathrm{cm}^{3}$ & $\sim 1.33$ & $\sim 1.4$ & $\sim 1.06$ \\
\hline Viscosity at $25^{\circ} \mathrm{C}, \mathrm{mPa} \cdot \mathrm{s}$ & $150,000-250,000$ & Thixotropic & 45,000 \\
\hline Pot life a $25^{\circ} \mathrm{C}$, minutes & 40 to 65 & 30 to 40 & 8 to 12 \\
\hline
\end{tabular}

Once cured, the bonded composite laminates were machined to size using a grinding disc. The specimens were cut to a nominal width of $20 \mathrm{~mm}$ and a length of $200 \mathrm{~mm}$ with an initial crack starter length of $50 \mathrm{~mm}$ from the load-line. The total thickness of each specimen was $\approx 4.3 \pm 0.1 \mathrm{~mm}$. Some specimens of non-adhesive joints were also performed for the aim of comparison.

\section{Experimental Methods}

Double Cantilever Beam (DCB) and End-Notched Flexure (ENF) test were performed to characterize the adhesive under pure mode I and pure mode II according to the standards ASTM D 5528-01 [5] and ASTM D7905/D7905M-14 [6], respectively. In Figure 1 the configuration of each test is schematically shown.
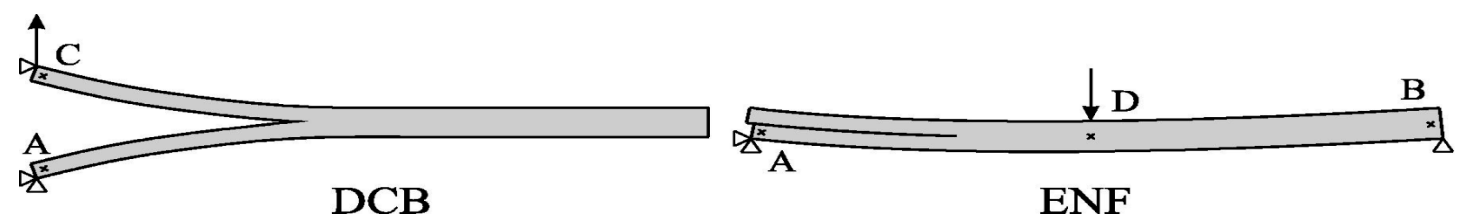

Figure 1. Representation of the load introduction in the two test types performed in this work II.

Specimens were tested under a displacement control on a servo-hydraulic testing machine (MTS 810) equipped with a $5 \mathrm{kN}$ load cell for both modes of fracture. All tests were carried out at a constant crosshead displacement rate of $3 \mathrm{~mm} / \mathrm{min}$. The crack length is monitored from images of the DCB specimen's edge recorded with a high resolution camera.

\subsection{DCB Test}

The procedure described in the standard ASTM D 5528-01 [5] was followed to perform the DCB test. The fracture toughness, Gic, were computed using the Beam Theory (BT) as follows (1):

$$
\mathrm{G}_{\mathrm{Ic}}=\frac{3 P \delta}{2 B a}
$$

where $P$ is the applied load, $\delta$ is the opening displacement, $B$ is the width of the specimen and $a$ is the crack length.

\subsection{ENF Test}

The three point bending ENF tests were done base on the procedure described in the standard ASTM D7905/D7905M-14 [6] (see Figure 1). The fracture toughness, GIIc, was calculated using (2):

$$
\mathrm{G}_{\mathrm{IIC}}=\frac{3 m P^{2}{ }_{\max } a_{\mathrm{O}}^{2}}{2 B}
$$

where $m$ is the CC coefficient, $P_{\max }$ is the maximum force from the fracture test, $a_{0}$ is the crack length used in the fracture test $(30 \mathrm{~mm}), B$ is the specimen width.

\section{Results}

Figure 2 shows the values of the initiation criteria of interlaminar fracture toughness (Gic and GIIC) for each adhesive joint system studied to compared with non-adhesive joints, for mode I and II, respectively. 


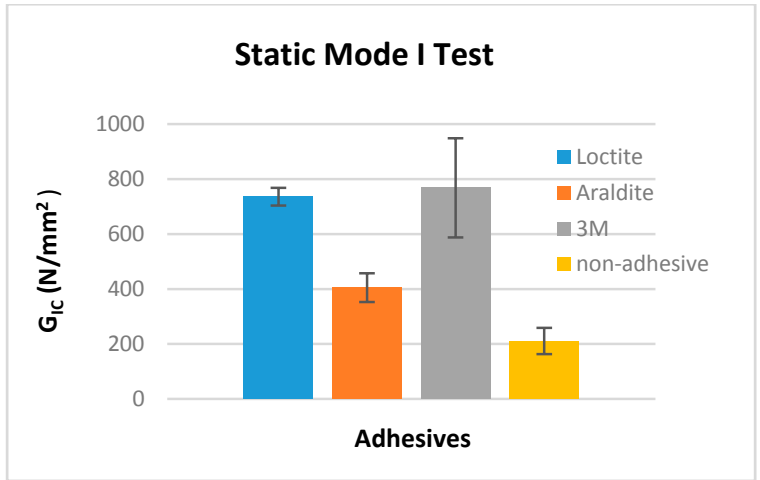

(a)

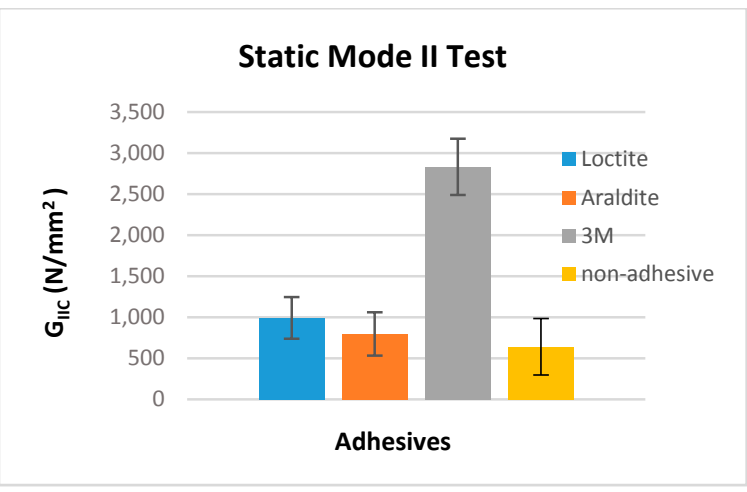

(b)

Figure 2. Interlaminar fracture toughness of the different adhesives used. (a) for mode I and (b) for mode II.

After testing, the specimens were manually broken apart to examine the fracture surfaces. Figure 3 shows the mode I and mode II fracture surface obtained for the different adhesives studied.

(1)

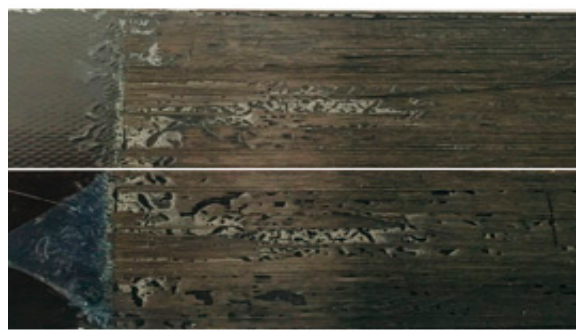

(2)

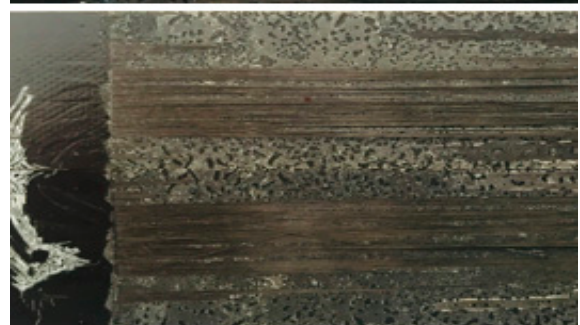

(3)

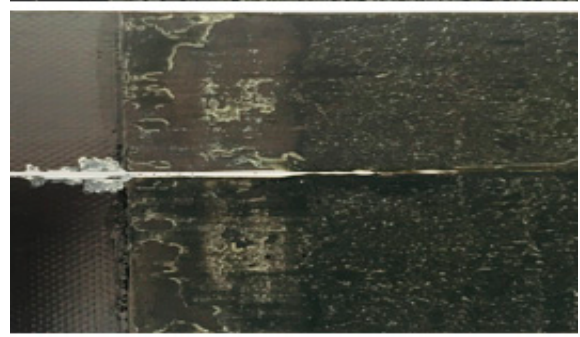

(a)
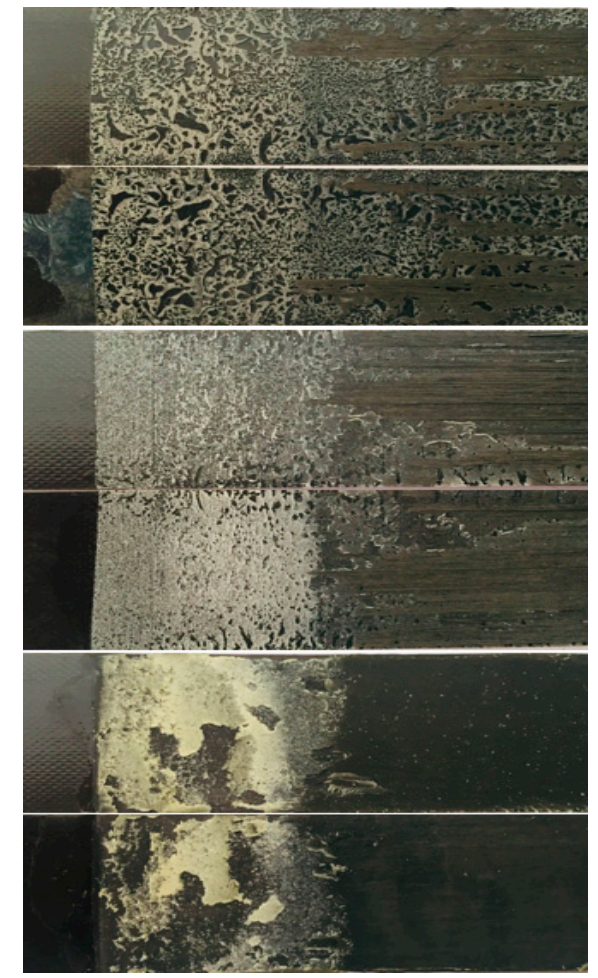

(b)

Figure 3. Fracture surfaces of the three adhesive joints. (a) Mode I: (1) Loctite ${ }^{\circledR}$ EA $9470^{\mathrm{TM}}$, (2)

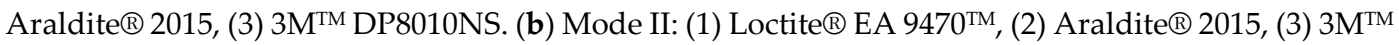
DP8010NS.

\section{Discussion}

According to the data obtained from the experimental tests, the 3M ${ }^{\mathrm{TM}}$ DP8010NS adhesive presents the highest values of strain energy release rate in mode I (GIC) and mode II (GIIC). In both cases, the behaviour of the adhesive joints improves the fracture toughness of the original material.

The errors bars for mode I are quite short except for $3 \mathrm{M}$ adhesive bonded joints. This is possible due to an effect caused by fibre-bridging which would positively contribute to the fracture toughness values. For mode II was observed similar error bars for each adhesive joint system and higher in comparison with mode I. 
This behaviour was confirmed by the study of the fractured surfaces of the specimens tested previously. In the region where the fracture test was conducted, it can be seen that the (1) Loctite ${ }^{\circledR}$ EA 9470T ${ }^{\mathrm{M}}$ and (2) Araldite ${ }^{\circledR} 2015$ adhesive joints failed interfacially while (3) 3M ${ }^{\mathrm{TM}}$ DP8010NS adhesive joints had had mix-fracture, adhesive failure for initiation region fracture and cohesive failure for propagation region.

For mode II test was observed the (1) Loctite ${ }^{\circledR}$ EA 9470T ${ }^{\mathrm{M}}$ and (2) Araldite ${ }^{\circledR} 2015$ adhesive joints failed interfacially while (3) 3MTM DP8010NS adhesive joints failed cohesively.

\section{Conclusions}

This work aims to study the behaviour against delamination under static modes I and II of adhesive bonded joints in unidirectional carbon-fibre/epoxy prepreg for different structural epoxy and acrylic adhesive.

For mode I, higher values of strain energy release rate were obtained in comparison with the original material for three different adhesive bonded joints used. The same trend is observed for mode II.

Fracture surfaces show a better delamination behaviour in cohesively failed than in interfacial failed. Acrylic adhesive tends to have cohesive failure while epoxy adhesives tends to have interfacial failure.

\section{References}

1. Budhe S.; Bane M.D.; de Barrosa S.; da Silva, L.F.M. An updated review of adhesively bonded joints in composite materials. Int. J. Adhes. Adhes. 2017, 72, 30-42.

2. Mollon, V.; Bonhomme, J.; Viña, J.; Arguelles, A.; Fernandez, A.C. Influence of the principal tensile stresses on delamination fracture mechanisms and their associated morphology for different loading modes in carbon/epoxy composites. Compos. Part B Eng. 2012, 43, 1676e80.

3. Sarrado, C.; Turon, A.; Costa, J.; Renart, J. An experimental analysis of the fracture behaviour of composite bonded joints in terms of cohesive laws. Compos. Part A 2016, 90, 234-242.

4. Mohan, J.; Ivankovic, A.; Murphy, N. Mode I fracture toughness of co-cured and secondary bonded composite joints. Int. J. Adhes. Adhes. 2014, 51, 13-22.

5. ASTM D 5528-01. Standard Test Method for Mode I Interlaminar Fracture Toughness of Unidirectional FiberReinforced Polymer Matrix Composites; ASTM: West Conshohocken, PA, USA, 2001.

6. ASTM D7905/D7905M-14. Standard Test Method for Determination of the Mode II Interlaminar Fracture Toughness of Unidirectional Fiber-Reinforced Polymer Matrix Composites; American Society for Testing and Materials: West Conshohocken, PA, USA, 2006.

(C) 2018 by the authors. Licensee MDPI, Basel, Switzerland. This article is an open access article distributed under the terms and conditions of the Creative Commons Attribution (CC BY) license (http://creativecommons.org/licenses/by/4.0/). 